\title{
Molecular Markers Based Identification of Diversity for Drought Tolerance in Bread Wheat Varieties and Synthetic Hexaploids
}

\author{
Zahid Hussain Shah ${ }^{a}$, Muhammad Munira, \\ Abdul Mujeeb Kazi ${ }^{b}$, Tahir Mujtaba ${ }^{a}$ \\ and Zaheer Ahmed ${ }^{\text {** }}$ \\ a Department of Plant Breeding and Genetics, Pir Mehr Ali \\ Shah Arid Agriculture University Rawalpindi, Pakistan. \\ ${ }^{b}$ Centre of Cytogenetic, National Agricultural Research \\ Center, Islamabad, Pakistan \\ c Department of Molecular and Cellular Biology, University \\ of Guelph, Canada
}

\begin{abstract}
The complexity of the wheat genome has delayed the development and application of molecular markers to this species and wheat now lies behind barley, maize and rice in marker development. However, improvements in marker detection systems and in the techniques used to identify markers linked to useful traits has allowed considerable advances to be made in recent years. To evaluate the genetic diversity 53 genotypes of Richard's selection, were studied at National Agriculture Reseach Center (NARC) Islamabad. The present study found that RAPD analysis is a valuable diagnostic tool. Different sets of RAPD primers were used to study the polymorphism at molecular level. Highest number of amplifications was shown by primer OpG-2 in Richard's material. Coefficient of similarity as well as genetic distances among these three sets of materials was calculated by using Unweighted Pair Group of Arithamatic Means (UPGMA) function (Nei and Li, 1979). The SHs derived genotypes of Richard's selection were highly polymorphic with a polymorphism percentage of 69.70 as compared to NUYT (rainfed) and elite Pakistani bread wheat varieties with a polymorphism of $44.44 \%$ and $61.11 \%$ respectively. Cluster analysis was done in which grouping of genotypes was done on the basis of genetic distances. Cluster analysis revealed that genotypes of Richard's genotypes are showing high level of among cultivar variation as compared to NUYT (Rainfed) and elite Pakistani drought tolerant bread wheat varieties. These genotypes were also phenotypically evaluated.
\end{abstract}

\section{Introduction}

It is vital for plant breeding programmes to have sufficient diversity available to allow for the production of new varieties that are aimed towards the improvement of crop productivity and able to withstand damage from biotic and abiotic factors. In this respect, efforts have also been made to predict the prospects of developing superior genotypes from a cross by the measurement of a genetic similarity (GS) or genetic distance (GD) between the parents, since

*Corresponding author: Email: zahmed@uoguelph.ca the later can be used as an estimation of expected genetic variances in different sets of segregating progenies derived, from different crosses. The availability of genetic variability in elite wheat material is pre requisite for any breeding programme aimed towards the improvement of wheat productivity. Wheat breeding through hybridization also requires the selection of diverse genotypes, irrespective of whether the end product is pure line or a hybrid variety.

Wheat is used mainly for human consumption and supports nearly $35 \%$ of the world population. It is nutritious, easy to store and transport and can be processed into various types of food. The demand for wheat is expected to grow faster than any other major agricultural crop. To meet the needs of the growing world population, the forecast demand for the year 2020 varies between 840 (Rosegrant et al. 1995) and 1050 million tons (Kronstad, 1998). Due to land limitations, the enhancement of wheat production must come from higher absolute yields, which can only be met by the concerted action of scientists involved in diverse agricultural disciplines and in particular by increased efforts in plant breeding (Braun et al. 1998). In addition to continuous investments in conventional breeding methods, the better understanding of the current and expanded genetic diversity and biotechnological tools should be considered for raising the yield frontier in wheat. Pakistan, as a developing country has less share in global wheat production. Its consumption is increasing day by day due to ever increasing population at 3.0 percent per anum Wheat occupies $70 \%$ of Rabi (winter season) and $37 \%$ of total cropped area in Pakistan. During the year 2005-2006, it has been cultivated on 8.33 million hectares with an annual production of 21.109 million tons. (Govt. of Pak. 2005-06). About $20 \%$ area of wheat is under rainfed condition, where moisture is the major limiting factor. Drought affects every aspect of the plant growth and the ability to yield well under stress is conditioned by different physiomorphic traits. Considerable efforts have been made in the past, in beeding for improved drought tolerance in field crops. Struggles have been made primarily to the use of empirical breeding approaches by concentrating on yield and components of yield in wheat. These traits are genetically complex and are not easy to manipulate, hence, little success has been achieved to develop drought tolerant wheat varieties over the last 50 years. A number of morphological traits like plant height, pubescence, pigmentation, and especially drought tolerance have been identified in wheat and are relatively simple in inheritance.

The best option for yield improvement and yield stability under soil moisture deficit conditions is to develop drought tolerant crop varieties through molecular approaches e.g application of molecular markers like RAPD (Randomly Amplified Polymorphic DNA). These makers are preferably used to detect polymorphism of genetic material of agronomically important drought tolerant cultivars. Molecular 
markers provide a direct measure of genetic diversity and go beyond indirect diversity measures based on agronomic traits or geographic origin. Simple sequence repeats are highly polymorphic in wheat and, therefore, suitable for the discrimination of genotypes. They are generally genome specific, abundant, codominant, and cover all 21 wheat chromosomes. They have been successfully employed to characterize genetic diversity in seed bank collections of improved wheat germplasm and wild relatives $(\mathrm{Li}$ et al. 2000 and Hammer, 2000). The germplasm improvement and genetic diversity is the key to durable and sustained production of wheat. The principal aim of this work was to enrich the gene pool of cultivated wheat varieties by tapping the vast genetic resources available in the plant's wild relatives. Priority candidates were $A$ and $D$ genome accessions for primary pool belonging to Triticum boeoticum, Triticum monococum, Triticum urartu and Aegilops tauschii (Syn Ae. Squarosa, Triticum tauschii). Objective of our conducted study was molecular characterization of germplasm by using RAPD and emphasizing primarily on $D$ genome.

Table 1. Pedigree List of Richard's Selection

\begin{tabular}{|c|c|}
\hline Pop\# & Pedigree \\
\hline 1 & EXCALIBUR/WBLL1 \\
\hline 2 & TEV2/FRET2 \\
\hline 3 & CETTIA/WBLL1 \\
\hline 4 & TC870344/GU1//TEMPORALERA M 87/AGR/3/WBLL1 \\
\hline 5 & PASTOR/3/KAUZ*2/OPATA//KAUZ/4/CHEN/AE.SQ//2*OPATA \\
\hline 6 & PVN/3/PRL/SARA/TSI/VEE\#5/4/WBLL1 \\
\hline 7 & BAV92/3/PRL/SARA/TSI/VEE\#5/4/WBLL1 \\
\hline 8 & PASTOR/3/URES/JUN//KAUZ/4/WBLL1 \\
\hline 9 & 1455/2*PASTOR \\
\hline 10 & AUS $4930.7 / 2 *$ PASTOR \\
\hline 11 & KRICHAUFF/2*PASTOR \\
\hline 12 & PAM94/3/ALTAR 84/AEGILOPS SQUAROSA(TAUS)//OPATA/PASTOR \\
\hline 13 & T. DICOCCON PI94625/AE.SQUAROSA (372)//FRET2/3/2*WBLL1 \\
\hline 14 & T.DICOCCON PI225332/AE.SQUAROSSA (895)//WBLL1/3/2*WBLL1 \\
\hline 15 & ATTILA/WBLL1 \\
\hline 16 & FRET2/3/CHEN/AE.SQ//2*OPATA \\
\hline 17 & FRET2/3/CHEN/AE.SQ//2*OPATA \\
\hline 18 & FRET2/3/CHEN/AE.SQ//2*OPATA \\
\hline 19 & $\begin{array}{l}\text { DOY1/AE.SQUAROSA(333)/3/PRL/VEE\#6//CHOIX/4/HAHN/PRL//CLMS/3/ } \\
\text { HAHN/PRL }\end{array}$ \\
\hline 20 & ARLIN_1/AE.SQUARROSA (1017)//ATTILA/3/ATTILA*2/M10 \\
\hline 21 & KLCQ/KASO2 \\
\hline 22 & TUI//2*SUNCO/SA1166/3/TUI/4/FINSI \\
\hline 23 & HXL7573/2*BAU//WBLL1 \\
\hline 24 & $\begin{array}{l}\text { GPO8 KAZAKSTAN } 6 \text { WM98-99/4/KAUZ//ALTAR 84/AOS/3/ KAUZ/5/ } \\
\text { /KAUZ//ALTAR 84/ AOS/3/KAUZ }\end{array}$ \\
\hline 25 & $\begin{array}{l}\text { 68.111/RGB-U//WARD/3/FGO/4/RABI/5/AE.SQUARROSA (882)/6/ } \\
\text { ATTILA/10/... }\end{array}$ \\
\hline 26 & $\mathrm{RABE} / 2^{\star} \mathrm{MO} 88 / 3 / \mathrm{CAZO} / \mathrm{KAUZ} / / \mathrm{KAUZ}$ \\
\hline 27 & URES/JUN//KAUZ/3/ALTAR 84/AE. SQ//2*OPATA \\
\hline 28 & CROC_1/AE.SQUARROSA (205)//KAUZ/3/ENEIDA/4/FINSI \\
\hline
\end{tabular}

\section{Materials and methods}

The experimental material comprised of 53 genotypes of Richard's selection (Table 1). This material was evaluated at National agriculture Research Centre (NARC) Islamabad.

\section{Molecular diagnostics}

The material was subjected to molecular evaluations for determining their DNA based diversity. This was done by using RAPD primers and the protocol is described below.

\section{DNA extraction}

In the growth room 5 to $7 \mathrm{~cm}$ long pieces of fresh leaf material were cut from the plants ( 3 week-old seedlings) and were placed in $1.5 \mathrm{ml}$ eppendorf tubes. The tubes were subsequently dropped in the liquid Nitrogen to rapidly freeze the leaf material. The plant material was then crushed to a fine powder with a knitting needle while still inside the tube. $500 \mu \mathrm{l}$ DNA extraction buffer ( $1 \%$ SDS, $100 \mathrm{mM} \mathrm{NaCl}, 100 \mathrm{mM}$ tris base, $100 \mathrm{mM} \mathrm{Na}_{2} \mathrm{EDTA}, \mathrm{PH}: 8.5$ by $\mathrm{HCl}$ ) was added to each eppendorf tube containing the crushed leaf material and was mixed well with the help of a knitting needle. $500 \mu \mathrm{l}$

\begin{tabular}{|c|c|}
\hline 29 & $\begin{array}{l}\text { FILIN/IRENA/5/CNDO/R143//ENTE/MEXI-2/3/AEGILOPS SQUAROSA } \\
\text { (TAUS)/4/WEAVER/6/... }\end{array}$ \\
\hline 30 & CNDO/R143//ENTE/MEXI_2/3/AEGILOPS SQUAROSA (TAUS)/4/OCI/5/... \\
\hline 31 & MILUN/BERKUT \\
\hline 32 & $\begin{array}{l}\text { FILI/IRENA/5/CNDO/R143//ENTE/MEXI_2/3/AEGILOPS SQUAROSA } \\
\text { (TAUS)/4/WEAVER/6/BERKUT }\end{array}$ \\
\hline 33 & $\begin{array}{l}\text { FILI/IRENA/5/CNDO/R143//ENTE/MEXI_2/3/AEGILOPS SQUAROSA } \\
\text { (TAUS)/4/WEAVER/6/BERKUT }\end{array}$ \\
\hline 34 & $\begin{array}{l}\text { FILIN/3/CROC_1/AE. SQUAROSA (205)//KAUZ/4/FILIN/5/VEE/MJI//2* } \\
\text { TUI/3/PASTOR }\end{array}$ \\
\hline 35 & $\begin{array}{l}\text { FILIN/3/CROC_1/AE. SQUAROSA (205)//KAUZ/4/FILIN/5/VEE/MJI//2* } \\
\text { TUI/3/PASTOR }\end{array}$ \\
\hline 36 & PRINIA/BERKUT \\
\hline 37 & CROC_1/AE. SQUAROSA (205)//KAUZ/3/PRL/SARA//TSI/VEE\#5 \\
\hline 38 & QT8343//PASTOR*2/OPATA \\
\hline 39 & JARU/3/URES/JUN//KAUZ/4/URES/JUN/KAUZ \\
\hline 40 & CROC_1/AE.SQUARROSA (205)//KAUZ/3/2*PJN/BOW//OPATA \\
\hline 41 & TAN//TEMPORALERA M 87/AGR/3/NG8319//SHA4/LIRA \\
\hline 42 & $\begin{array}{l}\text { BABAX/3/PRL/SARA//TSI/VEE\#5/4/CROC_1/AE.SQUARROSA } \\
(224) / / 2^{*} \text { OPATA }\end{array}$ \\
\hline 43 & JNRB.5/PIFED \\
\hline 44 & JNRB.5/PIFED \\
\hline 45 & CROC_1/AE.SQUAROSSA (205)//BORL95/3/KENNEDY \\
\hline 46 & $\begin{array}{l}\text { CNDO/R143//ENTE/MEXI_2/3/ AEGILOPS SQUARROSA (TAUS)/4/ } \\
\text { WEAVER/5/2*JANZ }\end{array}$ \\
\hline 47 & D67.2/P66.270// AE.SQUARROSA (320)/3/CUNNIGHAM \\
\hline 48 & CROC_1/AE.SQUAROSSA (205)//BORL95/3/KENNEDY \\
\hline 49 & CROC_1/AE.SQUAROSSA (205)//BORL95/3/KENNEDY \\
\hline 50 & CHEN/AEGILOPS SQUARROSA (TAUS)//BCN/3/BAV92 \\
\hline 51 & KAUZ*2/BOW//KAUZ/3/W98.6.38 \\
\hline 52 & SARA/THB//VEE/3/VEE/PJN//2*KAUZ \\
\hline 53 & CHEN/AE.SQ/WEAVER/3/ATTILA*2/M10(MUTATED C-306) \\
\hline
\end{tabular}


phenol: chloroform: isoamylalcohol (in the ratio of 25:24:1) was added and tubes were well shaken until a homogenous mixture is made. Samples were then centrifuged at 5000 rpm for 5 minutes. The aqueous phase (supernatant) was transferred to a fresh tube. To precipitate the DNA $50 \mu \mathrm{l}$ $3 \mathrm{M}$ sodium acetate $(\mathrm{pH}=4.8)$ and $500 \mu \mathrm{l}$ isopropanol was added to the tube and mixed gently. To make the DNA pellet, samples were centrifuged at $5000 \mathrm{rpm}$ for 5 minutes. After pouring the supernatant, pellet was washed with $70 \%$ ethyl alcohol. Pellet was dried at room temperature for an hour and was resuspended in $40 \mu \mathrm{l}$ TE buffer $(10 \mathrm{mM}$ Tris, $1 \mathrm{mM}$ EDTA and PH: 8.0) (Weining and Langridge, 1991). To remove RNA, DNA was treated with $40 \mu \mathrm{g}$ RNAase-A $(0.20 \mu \mathrm{l}$ of commercially supplied RNAase-A purchased from Gene Link, USA) at $37^{\circ} \mathrm{C}$ for 1 hour. After RNAase treatment, DNA samples were run on $1.0 \%$ gel to check the quality of DNA and then was stored at $4^{\circ} \mathrm{C}$. To use in Polymerase Chain Reaction (PCR) a 1:5 dilution of DNA was made in doubled distilled, deionized and autoclaved water.

Polymerase chain reaction

$P C R$ reactions were carried out in $25 \mu$ reaction containing 50-100 ng total genomic DNA templates, $0.25 \mu \mathrm{M}$ of each primer, $200 \mu \mathrm{M}$ of each dATP, dGTP, dCTP, dTTP, $50 \mathrm{mM}$ $\mathrm{KCl}, 10 \mathrm{mM}$ Tris, $1.5 \mathrm{mM} \mathrm{MgCl} 2$ and 2.5 units of Taq DNA polymerase. The amplification conditions were as; an initial step of denaturation for 1 minutes at $94^{\circ} \mathrm{C}$ followed by 45 cycles each consisting of a denaturation step of 1 minute at $94^{\circ} \mathrm{C}$, an annealing step of 1 minute at $34^{\circ} \mathrm{C}$ and an extension step of 2 minutes at $72^{\circ} \mathrm{C}$. Seven minutes were given after the last cycle to the extension step at $72^{\circ} \mathrm{C}$ to ensure the completion of the primer extension reaction. GeneAmp PCR system 2700 was used for all amplification reactions.

Gel electrophoresis

For electrophoresis of the amplification products, 1.5 $\%$ agarose/TBE gel was used. Gels were visualized by Ethidium Bromide under the UV light chamber and observed using the computer program UVIPhotoMW.

\section{DNA Marker}

The GeneRuler ${ }^{\mathrm{TM}} 1 \mathrm{~kb}$ DNA Ladder (Catalogue \# SM0313, Lot: 00018968 , Concentration: $0.1 \mu \mathrm{g} / \mu \mathrm{l})$ by Fermentas was used for sizing and approximate quantification of wide range double stranded DNA fragments on agarose gel. The ladder was premixed with 6X Loading Dye Solution for direct loading on gel.

Statistical analysis

For statistical analysis of RAPD the scorable bands were considered as a single locus/allele. The loci were scored as present or absent. Bivariate 1-0 data matrix was generated. Genetic distances were calculated using Unweighted Pair Group of Arithmetic Means (UPGMA) procedure as follows (Nei and Li, 1979).

$G D_{x y}=1-d_{x y} / d_{x}+d_{y}-d_{x y}$,

Where:

$\mathrm{GD}_{\mathrm{xy}}=$ Genetic distance between two genotypes, $\mathrm{x}(1)$ and $y(2)$

$d_{x y}=$ total number of common loci (bands) in two genotypes

$\mathrm{d}_{\mathrm{x}}=$ Total number of loci (bands) in genotype 1 and $\mathrm{d}_{\mathrm{y}}=$ Total number of loci (bands) in genotype 2 .

The 1-0 bivariate data matrix for each set of wheat lines based on the data of RAPD primers were used to construct dendrogram using computer program "Popgene32" version 1.31(The 1-0 bivariate data matrix for each set of wheat lines based on the data of RAPD primers were used to construct dendrogram using computer program "Popgene32" version 1.31 (http://www.ualberta.ca./ fyeh/fyeh).

\section{Results}

\section{Genetic diversity evaluation}

In this study PCR based random decamer primers were used. Randomly Amplified Polymorphic DNAs (RAPD) were used to detect genetic polymorphism at DNA level in 53 genotypes of Richard's selection.Only the scorable bands were included in the analyses. Every single band was considered as a single locus/allele for all the genetic analyses. The loci were scored as present / absent. Unweighted Pair Group of Arithamatic Means (UPGMA) function (Nei and Li, 1979) was used to estimate genetic distances between the genotypes.

\section{Genetic diversity evaluation of Richard's selection}

Out of total 46 available primers initially we used 10 primers and out of which 2 primers had shown relatively better amplification in terms of band number and sharpness. The total numbers of loci traced by these primers were 33 and out of these 21 were polymorphic. The percentage of polymorphism among these genotypes was $69.70 \%$. Figure 1 shows the amplification profile of 53 genotypes selected by Richard by using RAPD primer OpG-2(GGCACTGAGG). This primer has amplified highest number of genotypes. Maximum number of bands detected was three and minimum was one. Out of 53 genotypes the genomic DNA of 33 genotypes had been amplified by this primer. The size of scorable bands that were detected in amplification profile by using this primer ranged from 250 to $2500 \mathrm{bp}$.

According to Fig.1 three scorable bands were detected in genotypes number $1,4,3,5,6,7,10,11,14,15,16,17$ and 19. These genotypes were monomorphic for the band length of $750-2000 \mathrm{bp}$. Similarly three bands were scored in genotypes 30 and 31 having size of 500 to $1500 \mathrm{bp}$. Two scorable bands were detected in genotype number, 20, 21, $23,25,27,33$ and 37 , and the size of these scorable bands was from $250-1500 \mathrm{bp}$. One scorable band was detected in genotype number $30,32,34,35,36$, and 38 , and the size of this scorable band was from $500-750 \mathrm{bp}$. Two bands were scored in genotypes $40,41,44$ and 47 having a band size of 750 to $2000 \mathrm{bp}$. According Fig. 1 the band having a length of $1500 \mathrm{bp}$ was found in genotypes $1,2,3,4,5,6,10,11,15,16$ and 19 and this band was not found in remaining genotypes by using primer OpG-2. So these genotypes are monomorphic with respect to this band but polymorphic as compared with remaining genotypes that were lacking this band. A band of size 750 to $1000 \mathrm{bp}$ is present only in the genotypes $40,41,44$ and 47 these genotypes are monomorphic with respect to this band but polymorphic as compared with other genotypes. No amplification was shown by this primer in remaining genotypes, hence these were not included 

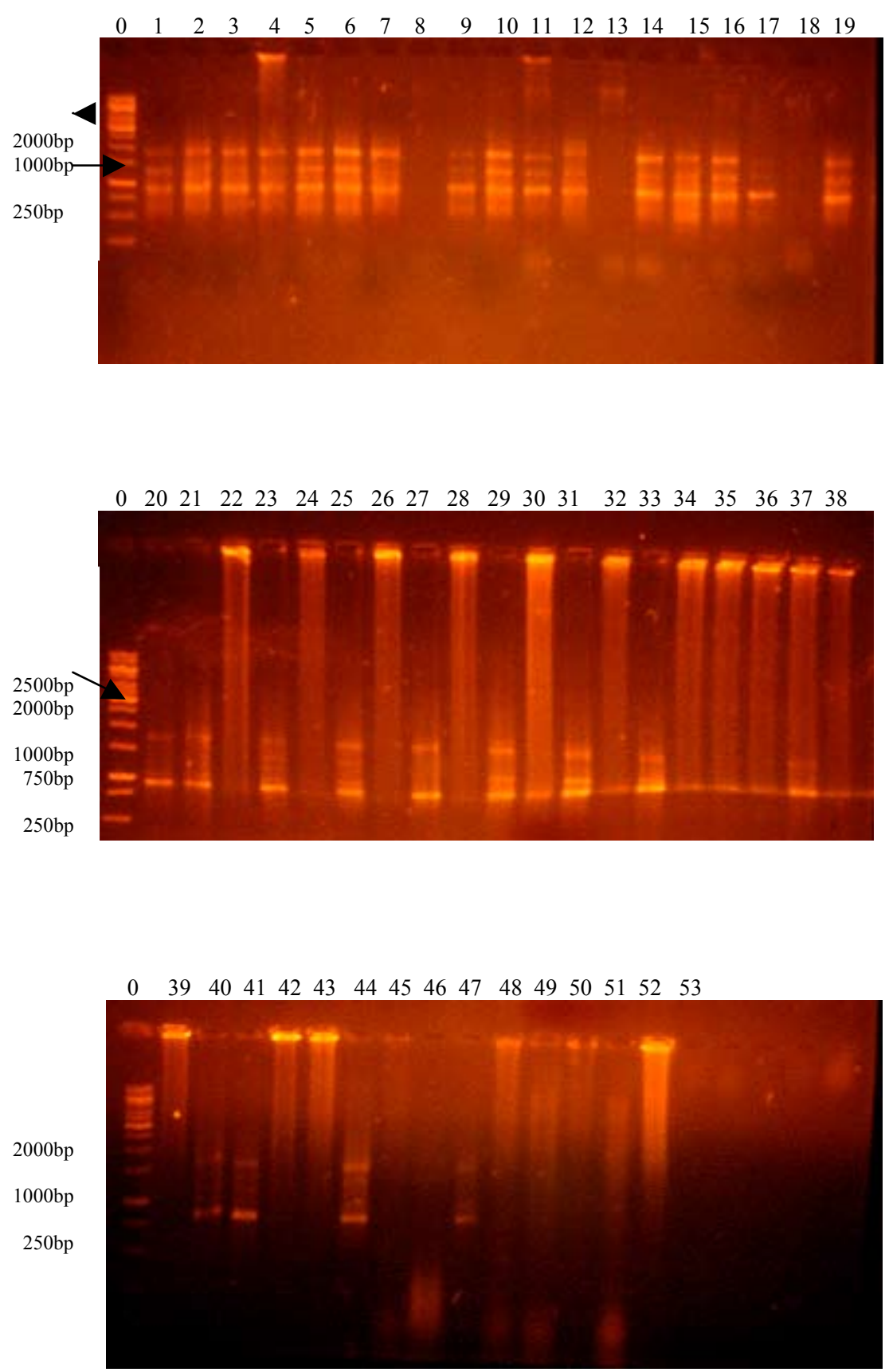

Figure 1. Agarose (1.7\%) gel showing PCR amplification products of decamer primer OpG-2 (GGCACTGAGG) from DNA of various wheat genotypes of Richard's selections. Lane 0 is molecular weight marker (GeneRulerTM 1kb DNA Ladder, Cat \# SM0313, Fermentas) and lanes 1-53 are representing the genotypes in the same order as indicated in Table 1.

in analysis. Other markers did not show amplifications in these genotypes. The value of similarity coefficient range from $0.6364(63.64 \%)-1.00(100 \%)$. Genotype 1and 8 are showing least similarity of $63.64 \%$.

\section{Dendogram interpretation of richard's genotypes}

For proper cluster analysis we devide it into four clusters A, B, C and D (Fig 2). Dendogram as shown in Fig. 3 has been formulated on the basis of genetic distances. CLUSTER A: This cluster include total twelve genotypes pop-1, pop-2, pop-5, pop-7,pop-9, pop-3, pop-11, pop-17, pop- 25,pop-29,pop-6 and pop-10(Sequence is in accordance to dendogram). In this cluster minimum genetic distance zero is present between pop-2, pop-5, pop-7 and pop-9. So we can say these genotypes are genetically identical and are not genetically diversified. In this cluster at point 43, pop-1 is showing maximum genetic diversity of 4.78 percent in comparison to the all members which are included in subcluster 40 .

The genetic distance of remaining genotypes of this cluster lies between the ranges of 0.00 to 4.78 percent. 


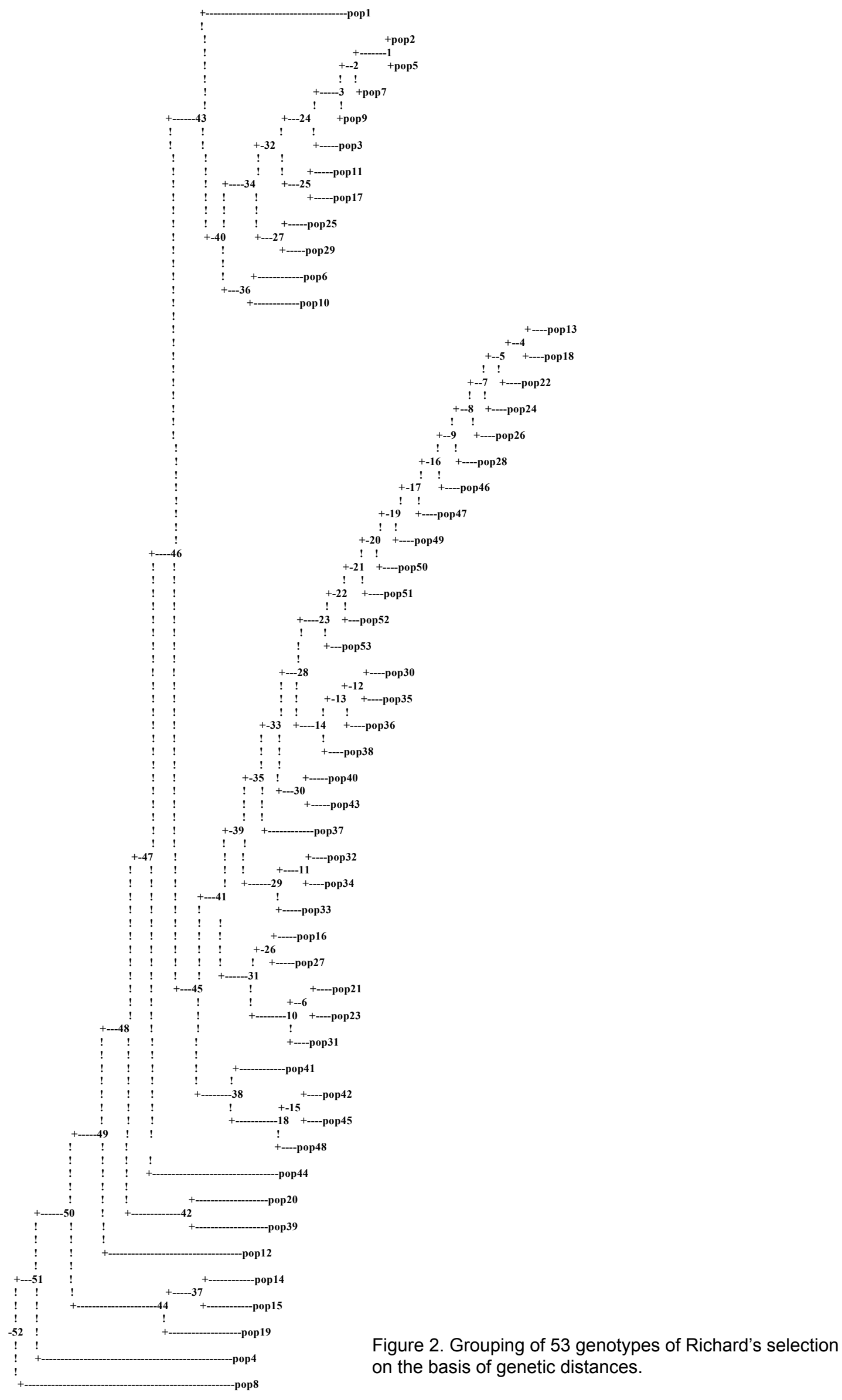




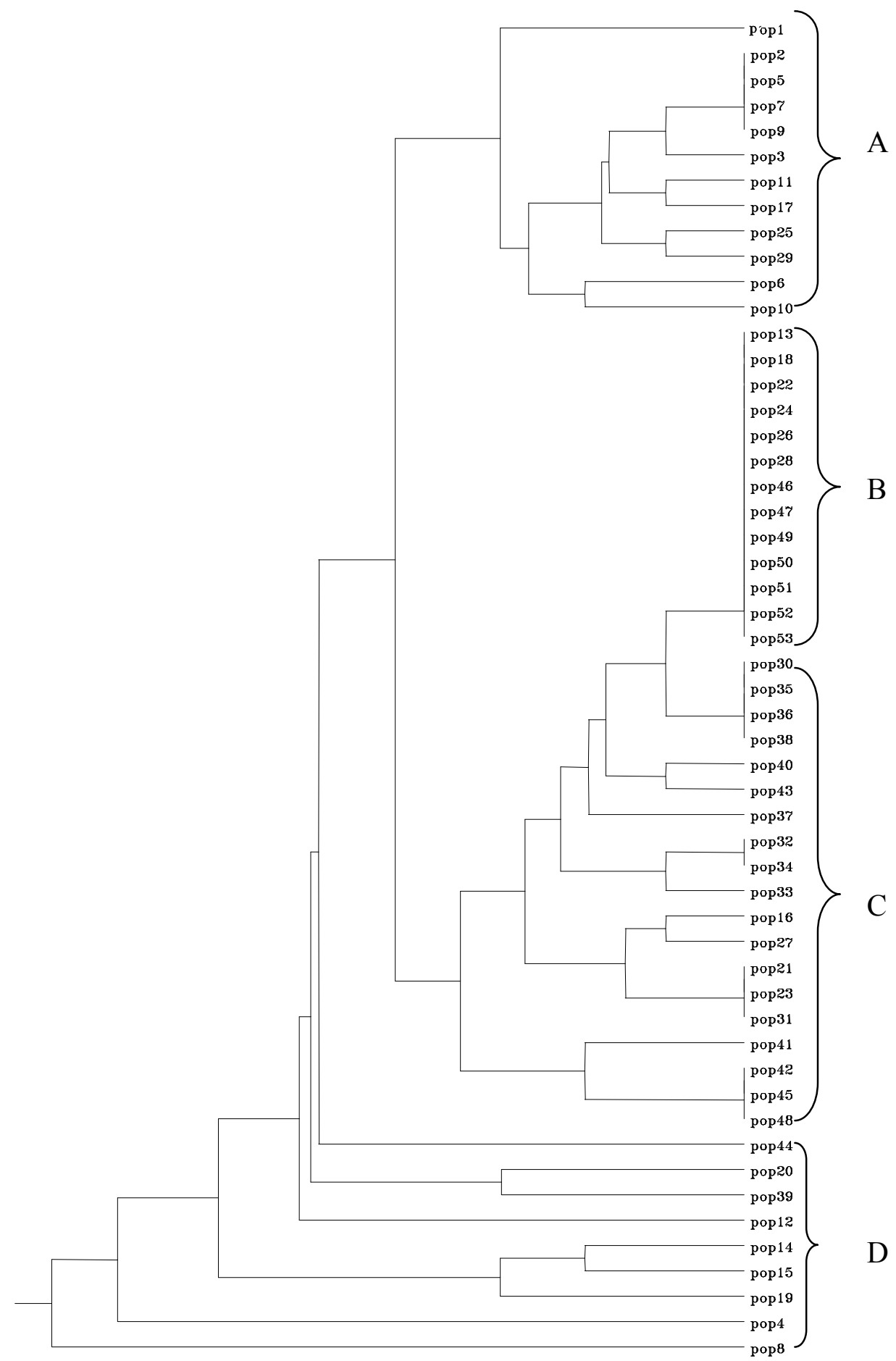

Figure 3. Dendogram formulated on the basis of genetic distances. See text for details.

CLUSTER B: This cluster include total twelve genotypes pop-13, pop-18,pop-22, pop-24, pop-26, pop-28,pop-46, pop47,pop-49,pop-50,pop-51,pop52 and pop-53. These genotypes show zero percent genetic diversity among them. So we can say these genotypes are identical. CLUSTER C: this cluster include total nineteen genotypes pop-30,pop35 , pop-36, pop-38, pop-40, pop-43, pop-37, pop-32, pop34, pop-33, pop-16, pop-27, pop-21, pop-23, pop-31, pop41 ,pop-42,pop-45 and pop-48. In this cluster zero percent genetic distance is present among genotypes, pop-30,pop-35,pop-36 and pop-38 pop-32 and pop-34 pop-21,pop-23 and pop-31 pop-42, pop-45 and pop-48 So genotypes which are showing zero percent genetic distance with each other are identical.

Within this cluster maximum genetic distance is shown by genotype pop-41. This genotype is showing a genetic 
distance of 3.13 percent with the genotypes pop-48, pop-45 and pop-42 which are included within group 38 of dendogram. So genotype pop-41 is showing more diversity within this cluster as compare to remaining genotypes. While the genetic distance of remaining genotypes lie within the range of 0.00 to $3.13 \%$. CLUSTER D: This cluster includes total nine genotypes i.e pop-44, pop-20, pop-39, pop-12, pop-14, pop-15, pop-19, pop-4 and pop-10. This cluster includes more genetically diversified genotypes i.e pop-8 and pop-4. These two genotypes are genetically more distinct as compare to the genotypes of all clusters. Pop-8 is showing a maximum genetic distance of 13.66 percent as compare to the all genotypes grouped at point 52 in dendogram. Similarly pop-4 is showing a genetic distance of 12.3 percent as compared to the all genotypes grouped at point 51 in dendogram. So pop-4 and pop-8 have shown high degree of polymorphism in molecular diversity analysis in comparison to the genotypes of all other clusters. From this cluster analysis it is revealed that pop-1, pop-4 and pop-8 are highly diversified genotypes. Genotypes of cluster A are showing a genetic distance of 2.07 percent with cluster $B$ and cluster $C$. While cluster $B$ is showing a genetic distance of 1.54 percent with cluster $C$. similarly Cluster $D$ is showing a genetic distance of 1.5 percent as compare to cluster $B$, cluster $\mathrm{C}$ and cluster $\mathrm{D}$.

\section{Discussion}

Over the past century, the development and successful application of plant breeding methods has produced highyielding crop varieties upon which modern agriculture is based. New varieties are usually bred by crossing a set of genetically related modern varieties, followed by an intensive selection in succeeding generations (Ceccarelli et al. 1987). Introduction of valuable genes from exotic donors via wide crosses has been proposed to broaden the genetic base of many crop plants with known and closely related wild relatives (Zohary et al.1969). Forms in the primary gene pool have genetic proximity to the genomes $A, B$, and $D$ of bread wheat thus all conventional wheat breeding utilizes its cultivars that reside in this gene pool (Coghlan 2006). Several types of diversity can be measured in the context of breeding programs (Smale et al. 1996). Apparent and latent genetic diversity are directly related to the performance of crops. Measures of apparent diversity are manifested in phenotypic differences of populations or cultivars in the field (Souza et al. 1994). Latent diversity refers to parentage analysis and molecular measurements that are not necessarily expressed in crop performance or phenotypes. Consequently, the genetic variation of crop plants is continued to be reduced by plant breeding (Tanksley and McCouch, 1997). It is the plant breeding process itself that threatens the genetic base on which breeding depends (Russell et al. 2000). In the light of these developments, the main objective of our research was to examine the genetic diversity in modern wheat breeding materials and genetic resources provided by and stored at CIMMYT. There has been a large transformation in the productivity of wheat due to the application of Green Revolution technology (Byerlee and Moya, 1993). The development of DNA markers in wheat is somewhat problematic due to three features. First, the size of the wheat genome $\left(16 \times 10^{9} \mathrm{bp}\right.$, compared to barley or maize with $5 \times 10^{9} \mathrm{bp}$ ), which makes the application of several marker techniques difficult. Second, the hexaploid nature of wheat adds complexity to many marker assays (Chao et al. 1989). Three sets of bands usually appear (often in the same size range), which are difficult to manage and interpret. Third, there is a generally low level of polymorphism in wheat relative to other cereal crops. This implies that a larger number of markers must be screened than in the case of rice, barley or maize (Chao et al. 1989; Lui et al. 1990). Furthermore, the level of polymorphism is not consistent across genomes and crosses. Commonly, the $D$ genome tends to have the poorest marker coverage (Chalmers et al. 2001). Lack of genetic polymorphism in crops such as wheat and soybeans, and the consequent problems to identify molecular markers, has been a major limitation to the impact of marker assisted selection (MAS) in wheat breeding (Sorrells and Wilson 1997).

Criteria for the estimation of genetic diversity can be different pedigree records, morphological traits or molecular markers (Heckenberger et al. 2002). Molecular markers detect variation of the DNA sequences among cultivars and therefore directly bypass problems connected with environmental effects (Cox et al. 1985 and Maric et al. 1998). In 1991 Welsh and McClelland (Welsh et al.1999) developed a new PCR-based genetic assay namely randomly amplified polymorphic DNA(RAPD). This procedure detects nucleotide sequence polymorphisms in DNA by using a single primer of arbitrary nucleotide sequence. On an average, each primer directs amplification of several discrete loci in the genome, making the assay useful for efficient screening of nucleotide sequence polymorphism between individuals (Tingey et al. 1993). During the past decade the focus shifted to surveys at the level of DNA. Using DNA markers, diversity is measured as the average allelic divergence between any two individuals for given loci (Huang et al. 2002). Sufficiently large numbers of samples allow robust analyses of open questions in population genetics (Hamrick and Godt 1990). The random amplified polymorphic DNA (RAPD) technique, regardless of its sensitivity to reaction conditions and problems with repeatability and amplifying of non-homologous sequences has been successfully used for the assessment of genetic diversity in diploid, tetraploid and hexaploid wheat (Sivolap et al. 1999). In hexaploid wheat, large genome size, a high proportion of repetitive DNAs, continuous inbreeding caused by self-pollination and a narrow genetic base represent the di.culties for use of molecular markers (Joshi and Nguyen, 1993). Knowledge of genetic diversity among adopted cultivars or elite breeding materials has a significant impact on the improvement of crop plants (Franco et al. 2001). It can be obtained from pedigree analysis, morphological traits or using molecular markers (Pejic et al. 1998). Molecular markers can support a more detailed characterization of genetic resources (Paull et al. 1998). A vast potential lies in their ability to identify the structure of genetic diversity within and among accessions, which can be of great importance for the optimization of collections, the planning of seed regeneration, and the successful implementation of prebreeding approaches (Borner et al. 2000).

SSRs show potential for large-scale DNA fingerprinting of wheat genotypes due to the high level of polymorphisms detected their ability to be analyzed using automated systems and their high accuracy and repeatability (Christiansen et al. 2002). The T1BL1RS translocation in wheat also has a demonstrated advantage in dry land wheat areas, and 
search for other diverse sources to exploit continues. One such unique gene pool resides in the primary Triticeae diploid Ae. tauschii (Dvorak et al. 1998). We have combined this diploid grass with elite durum cultivars to produce synthetic hexaploids. Field testing under reduced irrigation over the past several years have led to the identification of some synthetics classified as drought tolerant (Mujeeb-Kazi, 2003) evaluated that one successful method for introducing variation from the progenitors of BW into the elite breeding germplasm is the creation of synthetic hexaploid wheats (SHWs) (Mujeeb-Kazi et al. 1996). SSRs were applied to characterize the genetic relationships between hexaploid wheat landraces with different geographical origins and compare the results with a previous study carried out using AFLP and RAPD markers (Strelchenko et al. 2003). Simple sequence repeats (SSRs) represent the most suitable marker system in wheat (Li et al. 2000 and Hammer, 2000). They allow an even coverage of the genome, are abundant, genome specific, co-dominant in nature, and have been successfully used to characterize genetic diversity in advanced wheat breeding materials (Dreisigacker et al. (2004). The microsatellites, or Simple Sequence Repeat (SSRs), are PCR-based DNA markers that are highly polymorphic, show co-dominant inheritance, are evenly distributed throughout the genome and are locus-specific (Powell et al. 1996).

Drought is a major wheat production constraint, synthetic hexaploid yielded enormous desirable diversity when screened under reduced irrigation (Mujeeb Kazi, 1998). This whole study is basically a comparative study of elite Pakistani drought tolerant bread wheat varieties and $\mathrm{SHs}$ based derived lines. By using RAPD markers diversity is to be exploited at the molecular level. The annual increase in genetic potential in drought environments is only about half of that obtained in irrigated, optimum conditions (Trethowan et al. 2000). Genotypic analysis by using RAPD primer shows that SHs derived genotypes of Richards's selection are highly diversified as compare to Pakistani drought tolerant and rainfed genotypes. The polymorphism percentage among Richards's selection material was $69.70 \%$. This reveals that the $\mathrm{SHs}$ derived genotypes of Richards's selection are highly diversified, and can be used for the improvement of local Pakistani cultivars.

Among SHs based material, pop-1, pop-4 and pop-8 are showing maximum genetic distance of $4.78 \%, 12.3 \%$ and $13.66 \%$ respectively with remaining genotypes. The genetic enhancement of germplasm pools in breeding programes has largely resulted from the wider utilization of plant genetic resources (Rajaram and Van Ginkel 1996). Bread wheat contains perhaps $30 \%$ of the diversity levels found in its diploid relatives. With the development of SHWs, which repeat the natural hybridization event, genetic diversity of $T$. durum and T. tauschii can be incorporated into modern breeding lines (Galili et al. 2000) (Diaby and Casler 2003). However, due to the stoichastic nature of DNA amplification with random sequence primers, it is important to optimize and maintain consistent reaction conditions for reproducible DNA amplification. They are dominant markers and hence have limitations in their use as markers for mapping, which can be overcome to some extent by selecting those markers that are linked in coupling. RAPD assay has been used by several groups as efficient tools for identification of markers linked to agronomically important traits, which are introgressed during the development of near isogenic lines. The application of RAPDs and their related modified markers in variability analysis and individual-specific genotyping has largely been carried out, but is less popular due to problems such as poor reproducibility faint or fuzzy products, and difficulty in scoring bands, which lead to inappropriate inferences. The identification of a high number of polymorphisms in single sequence repeats (SSR) therefore should greatly enhance the potential to find molecular markers in wheat (Snape 1998). SSRs are relatively uncomplicated in their use because low amounts of DNA are required and the assay can be automated (Roder et al. 2002).

\section{Acknowledgement}

We highly acknowledge contribution of Dr. R. A. Richard from CIMMYT, for the provision of research material for this experiment.

\section{References}

Borner, A., S. Chebotar, and V. Korzun. 2000. Molecular characteriza tion of the genetic integrity of wheat (Triticum aestivum L.) germplasm after long-term maintenance. Theor. Appl. Genet. 100:494-497.

Braun, H.-J., T.S. Payne, A.I. Morgounov, M. van Ginkel, and S. Rajaram. 1998. The challenge: One billion tons of wheat by 2020. pp. 33-40. In A.E. Slinkard (ed.) Proc. Int. Wheat Genet. Symp., 9th, Saskatoon, Canada. 2-7 Aug. 1998. Extension Division,University of Saskatchewan, SK.

Byerlee, D., and P. Moya. 1993. Impacts of international wheat breeding research in the developing world, 1969-90. Mexico, D.F.: CIMMYT. 135pp.

Ceccarelli, S., M.M. Nachit, G.O. Ferrara, M.S. Mekni, M. Tahir, J. Van Leur, and J.P. Srivastava. 1987. Breeding strategies for improving cereal yield and stability under drought. pp. 101-114. In J.P. Srivastava, E. Porceddu, E. Acevedo, and S. Varma (eds.). Drought tolerance in winter cereals. John Wiley and Sons. New York. 387 pp.

Coghlan, A. 2006. Synthetic wheat offers hope to the world. New Scientist, $11^{\text {th }}$ February 2006.

Chalmers, K.J., A.W. Campbell, J. Kretschmer,A. Karakousis, P. Henschke, S. Pierens, N. Harker, M. Palotta, G.B. Cornish, M.R. Shariflou, L.R. Rampling, A. McLauchlan, G. Daggard, P.J. Sharp, T.A. Holton, M.W. Southerland, R. Appels, and P. Langridge.2001. Construction of three linkage maps in bread wheat, Triticum aestivum. Aust. J. Agric. Res. 52:1089-1119.

Chao, S., P.J. Sharp, A.J. Worland, E.J. Warham, R.M.D. Koebner, and M.D. Gale. 1989. RFLP-based genetic linkage maps of wheat homoeologous group 7 chromosomes. Theor. Appl. Genet. 78:495-504.

Christiansen M.J., S.B.Anderson. and R. Ortiz2002. Diversity changes in an intensively bread wheat germplasm during the $20^{\text {th }}$ century. Mol. Breed. 9: 1-11.

Cox, T. S., Y.T. Kiang, M.B. Gorman, and D.M. Rodgers.1985. Relationship between coeffcient of parentage and genetic similarity indices in the soybean. Crop Sci. 25, 529-532.

Diaby M. and Casler M.D. 2003. RAPD marker variation among smooth bromegrass cultivars. Crop Sci. 43: 1538-1547.

Dreisigacker, S., P. Zhang, M. van Ginkel, M. Warburton, D. Hoisington, M. Bohn, and A.E. Melchinger. 2004. SSR and 
pedigree analyses of genetic diversity among CIMMYT wheat lines targeted to different mega-environments. Crop Sci. In press.

Dvorak, J., M.C. Luo, Z.L. Yang, and H.B. Zhang. 1998. The structure of the Aegilops tauschii genpool and the evolution of hexaploid wheat. Theor. Appl. Genet. 97:657670.

Franco, J., J. Crossa, J. M. Ribaut, J. Betran, M. L. Warburton, and M. Khairallah, 2001: A method for combining molecular markers and phenotypic attributes for classifying plant genotypes. Theor. Appl. Genet. 103: 944-952.

Galili, S., Y. Avivi, E. Millet, and M. Feldman. 2000. RFLPbased analysis of there $R b c S$ subfamilies in diploid and polyploidy species of wheat. Mol. Gen. Genet. 263:674ñ 680.

Govt. of Pakistan. 2006. Economic Survey, Economic Advisory Wing, Finance Division, Islamabad

Hamrick, J.L., and M.J.W. Godt. 1990. Alloenzyme diversity in plant species.pp. 43-63. In Brown, A.H.D., M.T. Clegg, A.L. Kahler, B.S. Weir (eds.) Plant population genetics, breeding, and genetic resources. Sinauer Associates Inc., Sunderland, MA.

Hammer, K. 2000. Microsatellite markers as new tool for distinguishing diploid wheat species. Genet. Resour. Crop Evol. 47:497-505.

Heckenberg M., A.E. Melchinger, J.S. Ziegle, L.K. Joe, J.D. Hauser, M. Hutton and M. Bohn 2002. Variation of DNA fingerprints among accessions within maize inbred lines with regard to the identification of essentially derived varieties. I. Genetic and technical sources of variation in SSR data. Mol. Breed. 10: 181-191.

Huang, X.Q., A. Borner, M.S. Roder, and M.W. Ganal. 2002. Assessing genetic diversity of wheat (Triticum aestivum L.) germplasm using microsatellite markers. Theor. Appl. Genet. 105:699-707.

Jiang, J., B. Friebe, and B.S. Gill. 1994. Recent advances in alien gene transfer in wheat. Euphytica. 73: 199-212.

Joshi, C. P., and H. T. Nguyen, 1993: Application of the random amplified polymorphic DNA technique for detection of polymorphism among wild and cultivated tetraploidwheats. Genome 36:602-609.

Kimber, G. 1993. Genomic relationships in Triticum and the availability of alien germplasm. pp. 9-16. In Damania, A.B. (ed.) Biodiversity and wheat improvement, John Wiley and Sons, Chichester, UK.

Kronstad, W.E. 1998. Agricultural development and wheat breeding in the 20th century. Pp. 1-10. In Braun, H.-J., F. Altay, W.E. Kronstad, S.P.S. Benival, and A. McNAb (eds.) Wheat: Prospects for global improvement. Proc. of the 5th Int. Wheat Conf., Ankara, Turkey, Developments in Plant Breeding v. 6. Kluwer Academic Publishers, Dordrecht.

Li, Y.-C., T. Fahima, J.H. Peng, M.S. Roder, V.M. Kirzhner, A. Beiles, A.B. Korol, and E. Nevo. 2000. Edaphitic microsatellite DNA divergence in wild emmer wheat, Triticum dicoccoides, at a microsite: Tabigha, Israel. Theor. Appl. Genet. 101:1029-1038.

Lui, Y.G., N. Mori, K. Tsunewaki. 1990. Restriction fragment polymorphism (RFLP) analysis in wheat. I. Genomic DNA library construction and RFLP analysis in common wheat. Jap. J. Genet. 65:367-380.

Maric , S., M. Bede, J. Martincic, and V. Guberac, 1998: Variability of some winter wheat traits from breeding process. Sjemenarstvo 15, 421-433.
Morris, R. and E.R. Sears. 1967. The cytogenetics of wheat and its relatives. In Quinsberry, K.S. and L.P. Reiz (eds.). Wheat and wheat improvement. Agronomy Monograph 13. Am. Soc. of Agron. Inc., Madison, WI.

Mujeeb-Kazi A., V. Rosas and S. Roldan.1996. Conservation of the genetic variation of Triticum tauschii (Coss.). Schmalh. (Aegilops squarrosa auct. non L.) in synthetic hexaploid wheats ( $T$. turgidum L. x A. tauschii; $2 \mathrm{n}=6 \mathrm{x}$ $=42$, AABBDD) and its potential utilization for wheat improvement. Genet. Res. Crop. Evol. 43: 129-134.

Mujeeb-Kazi, A. 2003. New genetic stocks for durum and bread wheat improvement. Tenth International Wheat Genetics Symposium, Paestum, Italy, pp.772-774.

Mujeeb-Kazi, A., R. Delgado, A. Cortes, S.D. Cano, V. Rosas and J. Sanchez. 2004. Progress in exploiting Aegilops tauschii for wheat improvement. Annual Wheat Newsletter. 50:79-88.

Myburg, A. A., A. M. Botha, B. D. Wingeld, and W. J. M. Wilding. 1997.Identi.cation and genetic distance analysis of wheat cultivars using RAPD fingerprinting. Cereal Res. Comm. 25: 875-882.

Nei, N., and W. Li. 1979. Mathematical model for studying genetic variation in terms of restriction endonucleases. Proc. Natl. Acad. Sci. 76: 5269-5273.

Paull, J. G., K. J. Chalmers, A. Karakousis, J. M. Kretschmer, S. Manning, and P. Langridge,. 1998: Genetic diversity in Australian wheat cultivars and breeding material based on RFLP dana. Theor. Appl. Genet. 96:435-446.

Rajaram, S., M. van Ginkel, and R.A. Fischer. 1994. CIMMYT's wheat breeding mega-environments (ME). In Proceedings of the 8th International wheat genetic symposium, July 19-24, 1993. Beijing, China.

Rajaram, S., and M. van Ginkel. 1996. Wheat breeding methodology: International Perspectives. 1996.

Roder, M., K. Wendehake, V. Korzun, G. Bredemeijer, D. Laborie, B. Bertrand, P. Isaac, S. Rendel, J. Jackson, R.J. Cooke, B. Vosman, and M.W. Ganal. 2002. Construction and analysis of a microsatellite-based database of European wheat varieties. Theor. Appl. Genet. 106:67-73.

Roder, M.S., V. Korzun, K. Wendehake, J. Plaschke, M.H. Tixier, P. Leroy and M.W.Ganal. 1998. A microsatellite map of wheat. Genetics. 149:1-17.

Rosegrant, M.W., A. Agcaoili-Somlilla, and N. Perez. 1995. Global food projections to 2020. Discussion paper v. 5. IFPRI, WA. Russell J.R., Ellis R.P., Thomas W.T.B., Waugh R., Provan J., Booth A., Fuller J., Lawrence P., Young G. and Powell W. 2000.A retrospective analysis of spring barley germplasm development from 'foundation genotypes' to currently successful cultivars.Mol. Breed. 6: 553-568.

Sivolap, Y. M., S. V. Chebotar, E. A. Topchieva, V. N. Korzun, and V. N. Totskiy.1999. RAPD and SSRP analyses of molecular-genetic polymorphism in Triticum aestivum L. cultivars. Russian J. Genet. 35: 1433-1440.

Sorrells, M.E., and W.A. Wilson. 1997. Direct classification and selection of superior alleles for crop improvement. Crop Science. 37:691-697.

Snape, J.W. 1998. Golden calves or white elephants? Biotechnology for wheat improvement. Euphytica 100:207-217.

Strelchenko P., K. Street, O. Mitrofanova, M. Mackay, K. Chabane, J. Valkoun. 2003. The genetic relationships 
between hexaploid wheat landraces from different geographical origin. In 'Proc 10th Int Wheat Gen Symp. September 1-6, 2003, Paestum, Italy: vol 2, pp. 637-640

Tanksley S.D. and S.R. McCouch. 1997. Seed banks and molecular maps: Unblocking genetic potential from the wild. Science 277:1063-1066.

Trethowan, R, M.Van-Ginkel and A. Mujeeb-Kazi. 2000. Performance of advanced bread wheat and synthetic hexaploid derivatives under reduced irrigation. Annual Wheat Newsletter. 46:87-88.

Uddin, N., B.F. Carver, and A.C. Clutter. 1992. Genetic analysis and selection for wheat yield in drought-stressed and irrigated environments. Euphytica 62:89-96.

Zohary D., J.R. Harlan and A. Vardi. 1969. The wild diploid progenitors of wheat and their breeding value. Euphytica 18: 58-65. 


\section{Further Reading}

Caister Academic Press is a leading academic publisher of advanced texts in microbiology, molecular biology and medical research. Full details of all our publications at caister.com

- MALDI-TOF Mass Spectrometry in Microbiology Edited by: M Kostrzewa, S Schubert (2016) www.caister.com/malditof

- Aspergillus and Penicillium in the Post-genomic Era Edited by: RP Vries, IB Gelber, MR Andersen (2016) www.caister.com/aspergillus2

- The Bacteriocins: Current Knowledge and Future Prospects Edited by: RL Dorit, SM Roy, MA Riley (2016)

www.caister.com/bacteriocins

- Omics in Plant Disease Resistance Edited by: V Bhadauria (2016) www.caister.com/opd

- Acidophiles: Life in Extremely Acidic Environments Edited by: R Quatrini, DB Johnson (2016) www.caister.com/acidophiles

- Climate Change and Microbial Ecology: Current Research and Future Trend

Edited by: J Marxsen (2016)

www.caister.com/climate

- Biofilms in Bioremediation: Current Research and Emerging Technologies

Edited by: G Lear (2016)

www.caister.com/biorem

- Microalgae: Current Research and Applications Edited by: MN Tsaloglou (2016) www.caister.com/microalgae

- Gas Plasma Sterilization in Microbiology: Theory, Applications, Pitfalls and New Perspectives Edited by: H Shintani, A Sakudo (2016) www.caister.com/gasplasma

- Virus Evolution: Current Research and Future Directions Edited by: SC Weaver, M Denison, M Roossinck, et al. (2016) www.caister.com/virusevol

- Arboviruses: Molecular Biology, Evolution and Control Edited by: N Vasilakis, DJ Gubler (2016) www.caister.com/arbo

- Shigella: Molecular and Cellular Biology Edited by: WD Picking, WL Picking (2016) www.caister.com/shigella

-Aquatic Biofilms: Ecology, Water Quality and Wastewater Treatment

Edited by: AM Romaní, H Guasch, MD Balaguer (2016)

www.caister.com/aquaticbiofilms

- Alphaviruses: Current Biology

Edited by: S Mahalingam, L Herrero, B Herring (2016)

www.caister.com/alpha

- Thermophilic Microorganisms

Edited by: F Li (2015)

www.caister.com/thermophile
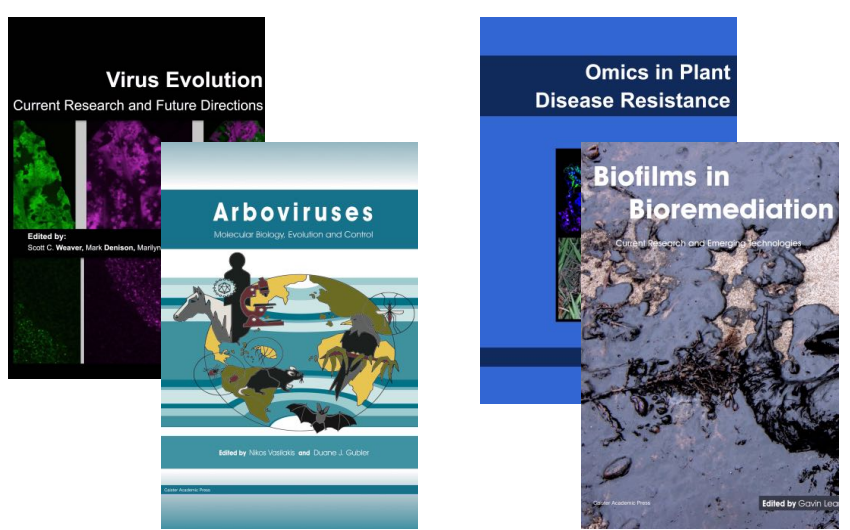
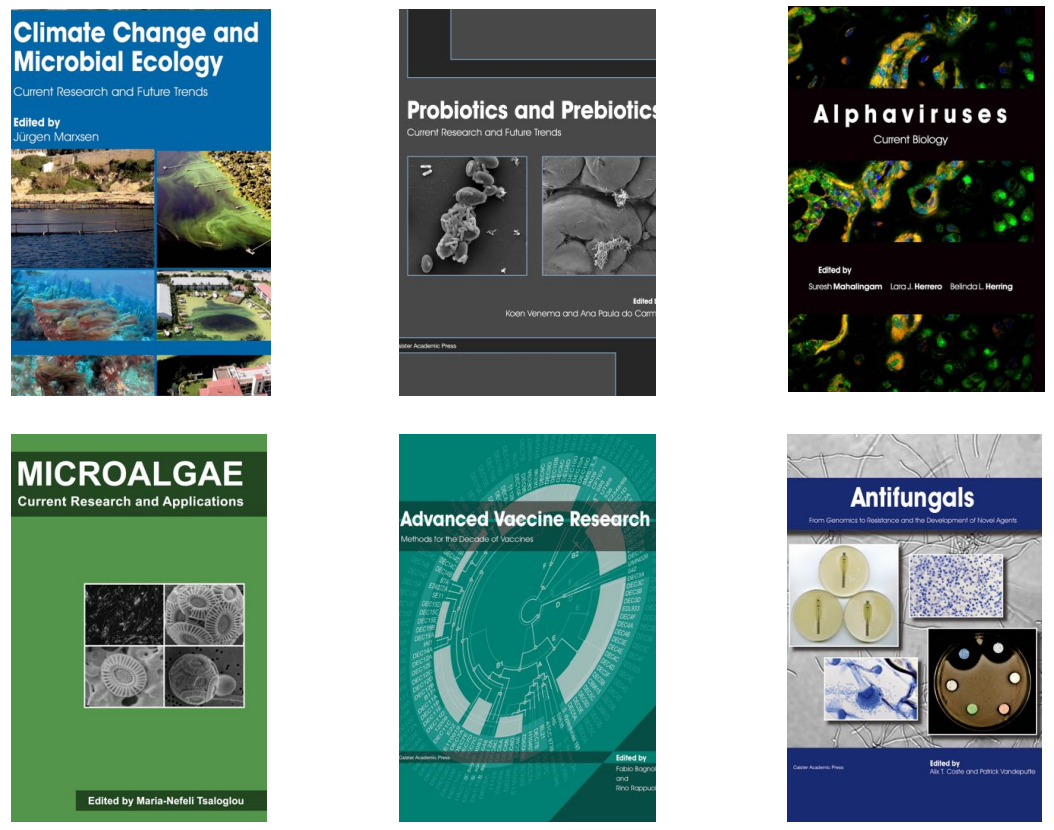

- Flow Cytometry in Microbiology: Technology and Applications Edited by: MG Wilkinson (2015) www.caister.com/flow

- Probiotics and Prebiotics: Current Research and Future Trends Edited by: K Venema, AP Carmo (2015) www.caister.com/probiotics

- Epigenetics: Current Research and Emerging Trends Edited by: BP Chadwick (2015) www.caister.com/epigenetics2015

- Corynebacterium glutamicum: From Systems Biology to Biotechnological Applications

Edited by: A Burkovski (2015)

www.caister.com/cory2

- Advanced Vaccine Research Methods for the Decade of Vaccines

Edited by: F Bagnoli, R Rappuoli (2015)

www.caister.com/vaccines

- Antifungals: From Genomics to Resistance and the Development of Novel Agents

Edited by: AT Coste, P Vandeputte (2015)

www.caister.com/antifungals

- Bacteria-Plant Interactions: Advanced Research and Future Trends Edited by: J Murillo, BA Vinatzer, RW Jackson, et al. (2015) www.caister.com/bacteria-plant

\section{- Aeromonas}

Edited by: J Graf (2015)

www.caister.com/aeromonas

- Antibiotics: Current Innovations and Future Trends

Edited by: S Sánchez, AL Demain (2015)

www.caister.com/antibiotics

- Leishmania: Current Biology and Contro Edited by: S Adak, R Datta (2015) www.caister.com/leish2

- Acanthamoeba: Biology and Pathogenesis (2nd edition) Author: NA Khan (2015)

www.caister.com/acanthamoeba2

- Microarrays: Current Technology, Innovations and Applications Edited by: Z He (2014)

www.caister.com/microarrays2

- Metagenomics of the Microbial Nitrogen Cycle: Theory, Methods and Applications

Edited by: D Marco (2014)

www.caister.com/n2 